\title{
PENINGKATAN DAYA SAING UKM MELALUI STANDARISASI PRODUK, PENGELOLAAN PENGETAHUAN DAN TEKNOLOGI INFORMASI
}

(Studi Kasus pada UKM Pengecoran Logam di Ceper - Klaten)

\author{
GL. Hery Prasetya \\ herianov@gmail.com
}

Jurusan Manajemen, Fakultas Ekonomi, Universitas Satya Negara Indonesia Jalan Arteri Pondok Indah No.11 Jakarta Selatan

\begin{abstract}
The role of SME in developing countries is relatively low, especially for their manufacturing product and competitiveness. Therefore, they get difficulties in increasing their output. The condition will be a challenge for Indonesian small and medium enterprises to improve their competitiveness. The current research is intended to know the effect of product standardization, knowledge management and information technology toward the increasing of competitiveness of metal faundry industry in Ceper - Klaten. Of 109 questionaries distributed, 76 ones are collected. Using regression analysis, it is derived that product standardization and knowledge management positively and significantly affect the competitiveness of SME meanwhile information technology doesn't affect the competitiveness of SME. Determination coefficient value $R$ square is $89,6 \%$ and the rest $10,4 \%$ is affected by other variables not discussed.
\end{abstract}

Keywords: Competitiveness, SME, Product Standardization, Knowledge Management and Information Technology

\section{PENDAHULUAN}

Di Indonesia UKM mempunyai peranan yang strategis dalam pembangunan, hal ini ditunjukkan dalam Rencana Pembangunan Jangka Panjang Nasional (RPJPN) 2005-2025 yang dinyatakan bahwa untuk memperkuat daya saing bangsa, salah satu kebijakan pembangunan dalam jangka panjang adalah memperkuat perekonomian domestik berbasis keunggulan masing-masing wilayah menuju keunggulan kompetitif. Perwujudan kebijakan ini dapat dilakukan salah satunya adalah melalui pengembangan UKM. Dengan dikeluarkannya Instruksi Presiden Nomor 6 Tahun 2007 tentang Percepatan Pengembangan Sektor Riil dan Usaha Mikro Kecil Menengah (UMKM), menunjukkan makin kuatnya posisi UKM dalam kebijakan pembangunan nasional. Persoalan mendasar dari hal tersebut adalah bagaimana implementasi kebijakan-kebijakan tersebut, sehingga UKM di Indonesia betul-betul menjadi pelaku ekonomi yang mempunyai kontribusi besar dalam memperkuat perekonomian domestik (Rahmana, 2009).

UKM memainkan peran yang sangat penting di dalam pembangunan dan pertumbuhan ekonomi, tidak hanya di negara-negara sedang berkembang tetapi juga di negara-negara maju. Peran UKM di negara sedang berkembang masih relatif rendah, khususnya pada produk- 
produk manufaktur dan ini yang menjadi perbedaan menyolok dengan UKM di negara maju. Salah satu fakta dari banyak studi empiris adalah rendahnya tingkat produktivitas UKM di negara sedang berkembang dibandingkan UKM di negara maju. Fakta kedua, dari sejumlah studi literatur adalah daya saing UKM yang rendah, sehingga kelompok usaha tersebut mengalami kesulitan dalam meningkatkan outputnya karena kalah bersaing, baik dengan produk-produk serupa yang dibuat oleh usaha besar di dalam negeri maupun dengan barangbarang impor (Tambunan, 2008).

Serbuan produk-produk impor khususnya dari Cina, dampak pemberlakuan ACFTA, membuat sebagian pengusaha dalam negeri berhenti beroperasi dan beralih menjadi pedagang (trader) akibat biaya produksi dalam negeri yang sangat tinggi. Akibatnya produk-produk yang dihasilkan tidak bisa bersaing dengan produk impor serupa yang sudah banyak di pasar domestik (Harian Bisnis Indonesia, 25 Oktober 2010). Salah satu upaya agar produk-produk dari sektor UKM dapat kompetitif dengan produk-produk dari negara lain adalah dengan meningkatkan kualitas daya saingnya (Rasbin dan Ginting, 2011).

Salah satu faktor penentu daya saing suatu produk adalah mutu (kualitas) produk itu sendiri. Untuk meningkatkan mutu produk maka performance produk tersebut harus mengacu dan sesuai dengan spesifikasi yang ditentukan atau standar. Standar berperan ganda, di satu sisi dapat dipakai sebagai alat bantu dalam perdagangan antar negara, pengakuan terhadap suatu standar (harmonisasi standar) antar negara-negara yang berdagang, dapat menghilangkan technical barrier. Sebaliknya penetapan standar nasional suatu negara dapat juga digunakan sebagai technical barrier yang berguna untuk melindungi produsen dalam negeri dari serbuan produk impor yang tidak bermutu (Arjadi, 2007).

Menurut Setiarso (2005), UKM perlu menggunakan strategi pengelolaan pengetahuan untuk meningkatkan daya saing UKM dengan menerapkan IRSA (Identify, Reflect, Share dan Application). Para pemimpin organisasi mulai memahami proses kreasi pengetahuan karyawan sebagai keunggulan daya saing perusahaan dengan memobilisasi pengetahuan karyawan dan menumbuhkan lingkungan belajar yang dapat mengakomodasi the new economics of information yang mulai merebak (Rachmany \& Akib, 2002). Tujuan penerapan konsep manajemen pengetahuan ini adalah untuk meningkatkan serta memperbaiki operasional perusahaan dalam mencapai keunggulan kompetitif.

Menurut Wysokinska (2003) dalam Rianto (2007), pertumbuhan produktivitas merupakan salah satu indikator daya saing tergantung pada sejumlah faktor, diantaranya yang paling penting adalah investasi pada sektor Teknologi Informasi (TI). TI merupakan suatu teknologi yang dapat menghadirkan informasi yang berkualitas, yaitu informasi yang relevan, tepat waktu dan akurat, untuk berbagai kepentingan pengguna. TI menggunakan teknologi komputer dan teknologi jaringan untuk menghasilkan berbagai produk yang praktis serta layanan informatika yang terintegrasi, memberikan kemudahan, dan bersifat global. Pengalaman di beberapa negara menunjukkan bahwa adopsi TI oleh perusahaan dapat meningkatkan efektivitas dan efisiensi kerja serta meningkatkan produktivitas perusahaan, yang pada akhirnya meningkatkan daya saing perusahaan tersebut. 


\section{KERANGKA PEMIKIRAN TEORITIS}

\section{Daya Saing}

Altenburg et al. (1998) mengemukakan bahwa daya saing sebuah perusahaan merupakan kemampuan untuk mempertahankan posisi pasar dengan mensuplai produk secara tepat waktu dan pada harga yang kompetitif melalui fleksibelitas untuk merespon perubahan permintaan secara cepat dan melalui manajemen diferensiasi produk yang sukses dengan membangun kapasitas inovatif dan sistem pemasaran yang efektif. Daya saing bermakna kekuatan untuk berusaha menjadi unggul dalam hal tertentu yang dilakukan seseorang, kelompok atau institusi tertentu (Sumihardjo, 2011).

Menurut Peraturan Menteri Pendidikan Nasional No. 41 Tahun 2007 tentang Standar Proses, dinyatakan bahwa daya saing adalah kemampuan untuk menunjukkan hasil lebih baik, lebih cepat atau lebih bermakna. Kemampuan yang dimaksud dalam Permendiknas No. 41 Tahun 2007 tersebut, diperjelas lagi yang meliputi : kemampuan memperkokoh posisi pasarnya, kemampuan menghubungkan dengan lingkungannya, kemampuan meningkatkan kinerja tanpa henti, dan kemampuan menegakkan posisi yang menguntungkan (Daryanto dan Hafizrianda, 2010).

Daya saing suatu produk UKM mencerminkan daya saing suatu perusahaan dimana daya saing perusahaan dipengaruhi oleh banyak faktor, yakni keahlian atau tingkat pendidikan pekerja, keahlian pengusaha, ketersediaan modal, sistem organisasi dan manajemen yang baik, ketersediaan teknologi, ketersediaan informasi, dan ketersediaan input-input lainnya (Tambunan, 2009). Artinya apabila faktor-faktor ini dikembangkan dengan serius, maka dapat meningkatkan daya saing perusahaan. Sehingga akhirnya daya saing produk-produk yang dihasilkan dapat meningkat.

\section{Usaha Kecil Menengah (UKM)}

Menurut UU No. 20 Tahun 2008, Usaha Kecil adalah usaha ekonomi produktif yang berdiri sendiri, yang dilakukan oleh orang perorangan atau badan usaha yang bukan merupakan anak perusahaan atau bukan cabang perusahaan yang dimiliki, dikuasai, atau menjadi bagian baik langsung maupun tidak langsung dari usaha menengah atau usaha besar yang memenuhi kriteria Usaha Kecil sebagaimana dimaksud dalam UU UMKM.

Dalam perspektif perkembangannya, UKM dapat diklasifikasikan menjadi 4 (empat) kelompok, yaitu :

a. Livelihood Activities, merupakan UKM yang digunakan sebagai kesempatan kerja untuk mencari nafkah, yang lebih umum dikenal sebagai sektor informal. Contohnya adalah pedagang kaki lima.

b. Micro Enterprise, merupakan UKM yang memiliki sifat pengrajin tetapi belum memiliki sifat kewirausahaan.

c. Small Dynamic Enterprise, merupakan UKM yang telah memiliki jiwa kewirausahaan dan mampu menerima pekerjaan subkontrak dan ekspor.

d. Fast Moving Enterprise, merupakan UKM yang telah memiliki jiwa kewirausahaan dan akan melakukan transformasi menjadi usaha besar.

\section{Standarisasi Produk}

Menurut De Vries (1999) standarisasi merupakan suatu pelumas bagi kalangan industri modern. Pada perusahaan, tujuan utama standarisasi terletak pada kontribusinya terhadap hasil bisnis. Sesuai atau tidaknya suatu hasil dengan standar tertentu dapat dibedakan melalui kesuksesan atau kegagalannya di pasaran. Tujuan utama standarisasi juga pada efektifitas serta efisiensi organisasi dimana bahwa standarisasi akan mengurangi biaya produk dan jasa. 
Sementara Sudarwo (2007) dalam Susanty (2009) menyatakan bahwa standar produk mengatur karakteristik teknis suatu produk untuk berbagai konteks keperluan. Beberapa keperluan yang penting adalah varitas produk, kompatibilitas atau interoperabilitas antar produk, persyaratan minimum produk, dan peringkat kualitas produk.

Menurut National Standardization Strategic Framework (http:/www.bsigroup.com, 2009) standar merupakan suatu bagian utama dari infrastruktur yang mendukung inovasi yang efisien. Standar memberi fokus pada dampak kritis dalam pasar produk dan jasa. Standar membentuk suatu bagian penting dari kondisi kerangka kerja bagi bisnis dan mempengaruhi kemungkinan rute dalam mencapai pasar atau validitas kelegalan dari yang ditawarkan pasar.

\section{Pengelolaan Pengetahuan}

Skyrme (2003) mendefinisikan manajemen pengetahuan sebagai suatu proses yang dapat menolong organisasi menemukan, memilih, menyebarkan, dan memindahkan informasi yang penting dan diperlukan untuk berbagai aktivitas seperti penyelesaian masalah, proses pembelajaran yang dinamis, serta strategi perencanaan dan pengambilan keputusan. Secara umum, manajemen pengetahuan adalah sebuah proses yang mengkoordinasikan penggunaan informasi, pengetahuan dan pengalaman.

Menurut Tiwana Amrit (Prentice Hall, 2000) dalam bukunya yang berjudul "the knowledge management toolkit: practical techniques for building a knowledge management system tidak memberikan jawaban dari pertanyaan yang generik, tetapi memberi petunjuk praktis untuk menghubungkan knowledge management dengan strategi bisnis. Knowledge management secara luas diartikan sebagai pengelola atau manajemen dari knowledge organisasi untuk menciptakan nilai bisnis dan membangun daya saing. Pengelolaan pengetahuan mampu untuk menciptakan, mengkomunikasikan, dan mengaplikasikan pengetahuan ke segala macam kegiatan bisnis untuk pencapaian tujuan bisnis. Pengertian lain dari knowledge management adalah kemampuan untuk menciptakan dan mempertahankan peningkatan nilai dari inti kompetensi bisnis. Karena itu perusahaan yang sukses dalam meningkatkan daya saingnya dicirikan pada kemampuan mereka untuk secara konsisten mengembangkan knowledge baru, yang disebarluaskan secara cepat dan dikaitkan dengan produk dan jasa baru. Jadi knowledge inilah yang akan mengembangkan inovasi, produk, proses atau jasa.

\section{Teknologi Informasi (TI)}

Teknologi Informasi merupakan suatu teknologi yang dapat menghadirkan informasi yang berkualitas, yaitu informasi yang relevan, tepat waktu, dan akurat, untuk berbagai kepentingan pengguna. TI menggunakan teknologi komputer dan teknologi jaringan untuk menghasilkan berbagai produk yang praktis serta layanan informatika yang terintegrasi, memberikan kemudahan, dan bersifat global. Pengalaman di beberapa negara menunjukkan bahwa penggunaan TI oleh perusahaan dapat meningkatkan efektivitas dan efisiensi kerja serta meningkatkan produktivitas perusahaan, yang pada akhirnya meningkatkan daya saing perusahaan tersebut (Rianto, 2007). Teknologi informasi juga akan membawa perusahaan pada kondisi yang menguntungkan yaitu kemudahan memasuki pasar, diferensiasi produk, dan cost efficiency (Kettinger et al, 1994).

Dalam perekonomian digital seperti sekarang ini, untuk mencapai keunggulan kompetitif penting sekali menekankan pada aspek kecepatan. Kecepatan dalam hal ini dapat meliputi bagaimana perusahaan mendapatkan data dan mengolahnya menjadi informasi dengan segera dan kemudian menggunakan informasi tersebut untuk merespon setiap kejadian dan masalah lingkungan dengan cepat, sehingga perusahaan dapat segera merespon perubahan-perubahan lingkungan. Untuk mengatasi masalah kecepatan ini, beberapa tahun terakhir telah banyak 
perusahaan memanfaatkan teknologi informasi (TI) untuk mengoptimalkan proses bisnis yang dimilikinya. Di samping kecepatan, penggunaan TI dapat memberikan alat-alat yang dapat meningkatkan keberhasilan perusahaan melalui sumber-sumber keunggulan kompetitif tradisional perusahaan seperti biaya rendah, layanan pelanggan yang sangat baik atau manajemen rantai pasokan yang superior (Widayanti, 2008).

\section{Pengembangan Hipotesis}

a. $\mathrm{H}_{1}$ : Standarisasi Produk berpengaruh Positif terhadap Daya Saing UKM

Salah satu faktor penentu daya saing suatu produk adalah mutu (kualitas) produk itu sendiri. Untuk meningkatkan mutu produk maka performance produk tersebut harus mengacu dan sesuai dengan spesifikasi yang ditentukan atau standar. Standar berperan ganda, di satu sisi dapat dipakai sebagai alat bantu dalam perdagangan antar negara, pengakuan terhadap suatu standar (harmonisasi standar) antar negara-negara yang berdagang, dapat menghilangkan technical barrier. Sebaliknya penetapan standar nasional suatu negara dapat juga digunakan sebagai technical barrier yang berguna untuk melindungi produsen dalam negeri dari serbuan produk impor yang tidak bermutu (Arjadi, 2007).

b. $\mathrm{H}_{2}$ : Pengelolaan Pengetahuan berpengaruh Positif terhadap Daya Saing UKM

Menurut Tiwana Amrit (Prentice Hall, 2000), perusahaan yang sukses dalam meningkatkan daya saingnya dicirikan pada kemampuan mereka untuk secara konsisten mengembangkan knowledge baru, yang disebarluaskan secara cepat dan dikaitkan dengan produk dan jasa baru. Pengelolaan pengetahuan dapat diartikan juga sebagai pengetahuansuatu organisasi untuk menciptakan nilai bisnis dan membangun daya saing. Muttaqien (2006) mengatakan bahwa tujuan penerapan konsep manajemen pengetahuan ini adalah untuk meningkatkan serta memperbaiki operasional perusahaan dalam mencapai keunggulan kompetitif.

c. $\mathrm{H}_{3}$ : Teknologi Informasi berpengaruh Positif terhadap Daya Saing UKM

Teknologi Informasi merupakan suatu teknologi yang dapat menghadirkan informasi yang berkualitas, yaitu informasi yang relevan, tepat waktu, dan akurat, untuk berbagai kepentingan pengguna. TI menggunakan teknologi komputer dan teknologi jaringan untuk menghasilkan berbagai produk yang praktis serta layanan informatika yang terintegrasi, memberikan kemudahan, dan bersifat global. Pengalaman di beberapa negara menunjukkan bahwa penggunaan TI oleh perusahaan dapat meningkatkan efektivitas dan efisiensi kerja serta meningkatkan produktivitas perusahaan, yang pada akhirnya meningkatkan daya saing perusahaan tersebut (Rianto, 2007).

\section{METODE}

Penelitian ini dilakukan untuk memperoleh data mengenai standarisasi produk, pengelolaan pengetahuan dan teknologi informasi pelaku bisnis UKM pengecoran logam sehingga dapat dianalisis pengaruhnya terhadap daya saing UKM. Obyek penelitian ini adalah 109 UKM pengecoran logam di Ceper - Klaten. Responden dalam penelitian ini adalah pemilik atau manajer, karena keberhasilan suatu perusahaan dipengaruhi oleh peran serta para pemilik atau manajer itu sendiri.

Sedangkan sumber data dalam penelitian ini adalah sumber data primer. Data yang digunakan dalam penelitian ini adalah data primer yang didapat dari daftar pertanyaan/ kuesioner yang diberikan kepada responden dengan memilih jawaban dalam skala likert (1 - 
7). Metode yang digunakan dalam penelitian ini adalah metode sensus, yaitu dengan menggunakan sebanyak 109 UKM pengecoran logam yang ada di Ceper.

Variabel dan indikator yang digunakan dalam penelitian dapat dilihat dalam tabel 1 berikut ini:

Tabel 1

Variabel dan Indikator

\begin{tabular}{|c|c|}
\hline Variabel & Indikator \\
\hline $\begin{array}{l}\text { Standarisasi Produk } \\
\text { (Gudmundsson dkk, 2004) }\end{array}$ & $\begin{array}{l}\text { - } \text { Nilai Tambah } \\
\text { - Partner Strategis } \\
\text { - } \text { Teknologi } \\
\text { - Respon pada Pasar }\end{array}$ \\
\hline $\begin{array}{l}\text { Pengelolaan Pengetahuan } \\
\text { (Setiarso, 2005) }\end{array}$ & $\begin{array}{l}\text { - Pengalaman } \\
\text { - Pertimbangan } \\
\text { - Nilai } \\
\text { - Kepercayaan }\end{array}$ \\
\hline $\begin{array}{l}\text { Teknologi } \\
\text { (O’Brien, 2005) }\end{array}$ & $\begin{array}{l}\text { - Kecepatan } \\
\text { - Kemampuan Pemrosesan } \\
\text { Informasi } \\
\text { - Konektivitas Komputer } \\
\text { - Teknologi Internet }\end{array}$ \\
\hline $\begin{array}{l}\text { Daya Saing (Tambunan, } \\
\text { 2009) }\end{array}$ & $\begin{array}{l}\text { - Pangsa Pasar Dalam Negeri } \\
\text { - Nilai/Harga Produk } \\
\text { - Diversifikasi Pasar Domestik } \\
\text { - Kepuasan Konsumen }\end{array}$ \\
\hline
\end{tabular}

\section{Model Penelitian}

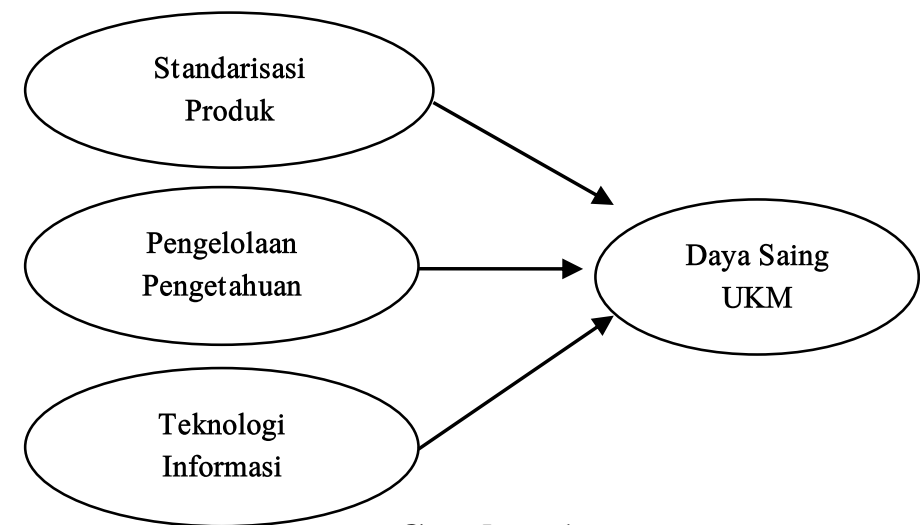

Gambar 1

\section{Model Penelitian}

Sumber: Rianto (2007), Muttaqien (2006) dan Arjadi (2007) 


\section{Metode Analisis Data}

\section{a. Analisis Kuantitatif}

Analisis kuantitatif merupakan pemrosesan dan manipulasi data mentah menjadi informasi yang bermanfaat. Analisis kuantitatif juga merupakan suatu analisis data yang diperlukan terhadap data yang diperoleh dari hasil responden yang diberikan, kemudian dilakukan analisis berdasarkan metode statistik dan data tersebut diklasifikasikan ke dalam kategori tertentu dengan menggunakan tabel untuk mempermudah dalam menganalisis (Ghozali, 2009).

b. Analisis Deskriptif

Analisis deskriptif bertujuan untuk memberikan suatu gambaran atau deskripsi suatu data yang dilihat dari nilai rata-rata (mean), standar deviasi, varian, maksimum, minimum, sum, range, kurtosis dan skewness (kemencengan) distribusi (Ghozali, 2011:19).

\section{c. Uji Realibilitas}

Realibilitas adalah alat ukur untuk mengukur suatu kuesioner yang merupakan indikator dari variabel atau konstruk. Suatu kuesioner dikatakan reliabel atau handal jika jawaban seseorang terhadap pernyataan adalah konsisten atau stabil dari waktu ke waktu (Ghozali, 2011:47-48).

\section{d. Uji Validitas}

Uji validitas digunakan untuk mengukur sah atau valid tidaknya suatu kuesioner. Suatu kuesioner dikatakan valid jika pertanyaan pada kuesioner mampu untuk mengungkapkan sesuatu yang akan diukur oleh kuesioner tersebut. Suatu instrumen yang valid atau sah mempunyai validitas yang tinggi, sebaliknya instrumen yang kurang valid berarti memiliki validitas yang rendah (Ghozali, 2011:53).

\section{e. Uji Asumsi Klasik}

Sebelum melakukan analisis data, maka data diuji sesuai asumsi klasik. Untuk mendapatkan model regresi yang baik, model regresi tersebut harus terbebas dari multikolinearitas dan heteroskedastisitas serta data yang dihasilkan harus berdistribusi normal.

\section{f. Analisis Regresi Linier Berganda}

Analisis regresi linier berganda (multiple regression) digunakan untuk menguji pengaruh lebih dari satu variabel bebas (metrik) terhadap satu variabel terikat metrik (Ghozali, 2011:17). Uji regresi linier berganda juga dapat menunjukkan arah hubungan antara variabel bebas (independent) dengan variabel terikat (dependent).

\section{g. Menilai Goodness of Fit Suatu Model}

Ketepatan fungsi regresi sampel dalam menaksir nilai aktual dapat diukur dari Goodness of fit-nya (Ghozali, 2011:97). Secara statistik hal tersebut dapat diukur dari nilai koefisien determinasi, nilai statistik $\mathrm{F}$ dan nilai statistik t. Perhitungan statistik disebut signifikan secara statistik apabila nilai uji statistiknya berada dalam daerah kritis (daerah dimana $\mathrm{H}_{0}$ ditolak). Sebaliknya disebut tidak signifikan bila nilai uji statistiknya berada dalam daerah dimana $\mathrm{H}_{0}$ diterima.

\section{PEMBAHASAN}

Analisis statistik deskriptif dalam penelitian ini digunakan untuk menghitung nilai ratarata (mean), standar deviasi (deviation standard), nilai maksimum dan nilai minimum pada variabel dependen Daya Saing UKM dan variabel independen Standarisasi Produk, Pengelolaan Pengetahuan dan Teknologi Informasi. 
Tabel 2

Hasil Uji Statistik Deskriptif

Deskritif Statistics

\begin{tabular}{|l|r|r|r|r|}
\hline & \multicolumn{1}{|c|}{ X1 } & \multicolumn{1}{|c|}{ X2 } & \multicolumn{1}{|c|}{ X3 } & \multicolumn{1}{|c|}{ Y } \\
\hline Valid & 76 & 76 & 76 & 76 \\
Missing & 0 & 0 & 0 & 0 \\
Mean & 20,0132 & 20,2237 & 20,3158 & 19,8553 \\
Std. & 3,16014 & 3,52741 & 2,74329 & 2,54403 \\
Deviation & & & & \\
Variance & 9,986 & 12,443 & 7,526 & 6,472 \\
Minimum & 12,00 & 12,00 & 12,00 & 16,00 \\
Maximum & 28,00 & 28,00 & 28,00 & 27,00 \\
Sum & 1521,00 & 1537,00 & 1544,00 & 1509,00 \\
\hline
\end{tabular}

Sumber: Data primer yang diolah (2014)

Berdasarkan tabel 2 tersebut dapat disimpulkan bahwa hasil perhitungan statistik deskriptif terlihat bahwa nilai minimum untuk variabel daya saing (Y), standarisasi produk $\left(\mathrm{X}_{1}\right)$, pengelolaan pengetahuan $\left(\mathrm{X}_{2}\right)$ dan teknologi informasi $\left(\mathrm{X}_{3}\right)$ masing-masing adalah 16, 12, 12 dan 12. Nilai maksimum untuk variabel daya saing, standarisasi produk, pengelolaan pengetahuan dan teknologi informasi masing-masing adalah 27, 28, 28 dan 28. Sedangkan nilai rata-rata untuk variabel daya saing, standarisasi produk, pengelolaan pengetahuan dan teknologi informasi masing-masing adalah 19,85; 20,01; 20,22 dan 20.31 dengan standar deviasi masing-masing adalah 2,54; 3,16; 3,52 dan 2,74. Hal ini menunjukkan bahwa variabel daya saing, standarisasi produk, pengelolaan pengetahuan dan teknologi informasi UKM relatif baik, karena besarnya angka rata-rata dari masingmasing variabel masih di atas angka standar deviasi.

\section{a. Uji Reliabilitas}

Uji reliabilitas digunakan untuk mengukur suatu kuesioner yang merupakan indikator dari variabel atau konstruk. Suatu kuesioner dikatakan reliabel atau handal jika jawaban seseorang terhadap pertanyaan dijawab responden secara konsisten atau stabil dari waktu ke waktu. Suatu konstruk atau variabel dikatakan reliabel jika memberikan nilai Cronbach Alpha lebih besar dari 0,70 (Ghozali, 2011:47). 
Tabel 3

Hasil Uji Reliabilitas

\begin{tabular}{cccc}
\hline Variabel & Ketentuan & Cronbach & Keterangan \\
& \multicolumn{3}{c}{ Alpha } \\
\hline $\mathrm{X}_{1}$ & $>0,70$ & 0,845 & Reliabel \\
$\mathrm{X}_{2}$ & $>0,70$ & 0,848 & Reliabel \\
$\mathrm{X}_{3}$ & $>0,70$ & 0,839 & Reliabel \\
$\mathrm{Y}$ & $>0,70$ & 0,830 & Reliabel \\
\hline
\end{tabular}

Sumber: Data primer yang diolah (2014)

Dari tabel 3 tersebut menunjukkan bahwa untuk indikator-indikator dari seluruh variabel yang ada dalam poin pertanyaan menunjukkan bahwa koefisien Cronbach's Alpha nilainya lebih dari 0,70 . Hal ini dapat disimpulkan bahwa keseluruhan variabel tersebut adalah reliabel.

\section{b. Uji Validitas}

Uji validitas digunakan untuk mengukur sah atau valid tidaknya suatu kuesioner. Suatu kuesioner dinyatakan valid jika pertanyaan pada kuesioner mampu untuk mengungkapkan sesuatu yang akan diukur oleh kuesioner tersebut. Uji validitas dilakukan dengan cara membandingkan nilai $\mathrm{r}$ hitung (correlation item total correlation) dengan nilai $r$ tabel dengan ketentuan untuk degree of freedom $(\mathrm{df})=\mathrm{n}-2$, dimana $\mathrm{n}$ adalah jumlah sampel. Jika $r$ hitung $>r$ tabel, berarti pernyataan tersebut dinyatakan valid. Namun apabila $\mathrm{r}$ hitung $<\mathrm{r}$ tabel, berarti pernyataan tersebut dinyatakan tidak valid (Ghozali, 2011:49).

Tabel 4

Hasil Uji Validitas

\begin{tabular}{cccc}
\hline Variabel & t hitung & $\mathbf{r}$ tabel & Keterangan \\
$\mathrm{X}_{1}$ & & & \\
$\mathrm{X}_{1.1}$ & 0,929 & 0,1901 & Valid \\
$\mathrm{X}_{1.2}$ & 0,904 & 0,1901 & Valid \\
$\mathrm{X}_{1.3}$ & 0,924 & 0,1901 & Valid \\
$\mathrm{X}_{1.4}$ & 0,928 & 0,1901 & Valid \\
$\mathrm{X}_{2}$ & & & \\
$\mathrm{X}_{2.1}$ & 0,938 & 0,1901 & Valid \\
\hline
\end{tabular}




\begin{tabular}{cccc}
\hline Variabel & t hitung & r tabel & Keterangan \\
$\mathrm{X}_{2.2}$ & 0,954 & 0,1901 & Valid \\
$\mathrm{X}_{2.3}$ & 0,926 & 0,1901 & Valid \\
$\mathrm{X}_{2.4}$ & 0,920 & 0,1901 & Valid \\
$\mathrm{X}_{3}$ & & & \\
$\mathrm{X}_{3.1}$ & 0,826 & 0,1901 & Valid \\
$\mathrm{X}_{3.2}$ & 0,725 & 0,1901 & Valid \\
$\mathrm{X}_{3.3}$ & 0,692 & 0,1901 & Valid \\
$\mathrm{X}_{3.4}$ & 0,908 & 0,1901 & Valid \\
$\mathrm{Y}$ & & & \\
$\mathrm{Y}_{1}$ & 0,485 & 0,1901 & Valid \\
$\mathrm{Y}_{2}$ & 0,573 & 0,1901 & Valid \\
$\mathrm{Y}_{3}$ & 0,561 & 0,1901 & Valid \\
$\mathrm{Y}_{4}$ & 0,767 & 0,1901 & Valid \\
\hline
\end{tabular}

Sumber: Data primer yang diolah (2014)

Berdasarkan tabel 4 di atas dapat dilihat uji validitas dari variabel standarisasi produk, pengelolaan pengetahuan, teknologi informasi dan daya saing menunjukkan bahwa pada korelasi masing-masing indikator terhadap total skor konstruk (pertanyaan) menunjukkan hasil yang signifikan dan $r$ hitung lebih besar dari $r$ tabel ( $r$ hitung $>r$ tabel). Jadi hal ini dapat disimpulkan bahwa masing-masing indikator pertanyaan adalah valid.

\section{c. Uji Asumsi Klasik}

\section{Uji Normalitas}

Uji normalitas digunakan untuk menguji apakah dalam model regresi, variabel pengganggu atau residual memiliki distribusi normal (Ghozali, 2011:147). Model regresi yang baik adalah memiliki distribusi residual normal atau mendekati normal. Ada dua cara untuk mendeteksi apakah residual berdistribusi normal atau tidak yaitu dengan analisis grafik (grafik histogram dan grafik normal probability plot) dan uji statistik (uji Kolmogorov Smirnov). 


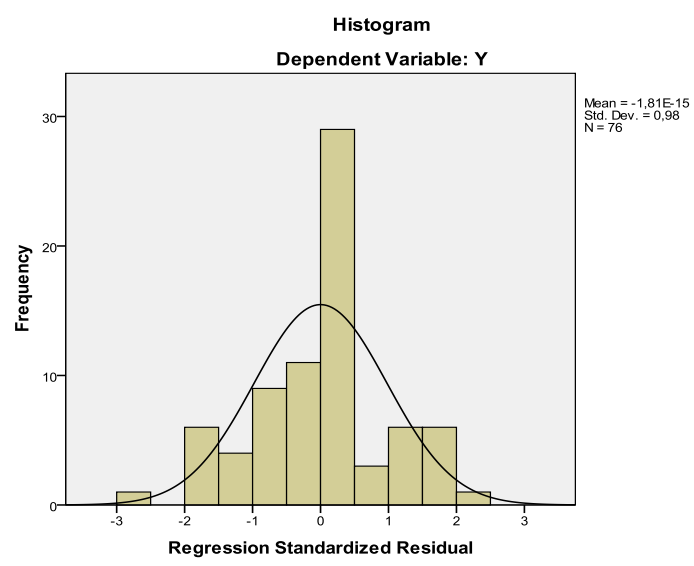

Gambar 2

\section{Hasil Uji Normalitas Histogram}

Sumber : Data primer yang diolah (2014)

Dari tampilan grafik histogram pada gambar 2 di atas dapat diketahui bahwa grafik histogram menunjukkan pola distribusi normal, yaitu grafik berada di tengah.Uji normalitas dengan grafik dapat menyesatkan apabila tidak hati-hati secara visual kelihatan normal, padahal secara statistik bisa sebaliknya. Oleh karena itu dianjurkan di samping uji grafik dilengkapi dengan uji statistik seperti dalam tabel berikut ini :

Tabel 5

Hasil Uji Kolmogorov Smirnov One-Sample Kolmogorov-Smirnov Test

\begin{tabular}{|c|c|c|}
\hline & & $\begin{array}{c}\text { Unstandardized } \\
\text { Residual }\end{array}$ \\
\hline $\mathrm{N}$ & & 76 \\
\hline Normal & Mean & ,0000000 \\
\hline Parameters & Std. Deviation & ,80411622 \\
\hline Most Extreme & Absolute &, 140 \\
\hline Dinerences & Positive & , 140 \\
\hline & Negative &,- 106 \\
\hline Kolmogorov-Sr & nirnov Z & 1,224 \\
\hline Asymp. Sig. (2- & tailed) & , 100 \\
\hline
\end{tabular}

a. Test distribution is Normal.

b. Calculated from data.

Sumber: Data primer yang diolah (2014) 
Berdasarkan tabel 5 tersebut menunjukkan bahwa besarnya nilai kolmogorov smirnov adalah sebesar 1,224 dan signifikan pada 0,100. Hal ini berarti data terdistribusi dengan normal karena nilai signifikansinya lebih besar dari $0,05(0,100>0,05)$. Jadi dapat disimpulkan bahwa model regresi memenuhi asumsi normalitas.

\section{Uji Multikolinieritas}

Uji multikolinieritas digunakan untuk menguji model regresi apakah ditemukan adanya korelasi antara variabel bebas (independent). Model regresi yang baik seharusnya tidak terjadi korelasi di antara variabel independent. Untuk mendeteksi ada atau tidaknya multikolinieritas di dalam model regresi adalah dengan membandingkan nilai tolerence dan variance inflation factor (VIF). Nilai cut off yang umum adalah nilai tolerence 0,10 atau nilai VIF 10. Jadi multikolinieritas terjadi jika nilai tolerence $<0,10$ atau nilai VIF $>$ 10. Untuk besaran korelasiantar variabel independen pedoman suatu model regresi yang bebas multikolinieritas adalah koefisien antar variabel independen haruslah lemah (dibawah 95\%). Jika korelasi kuat, maka terjadi masalah multikolinieritas. Bila ada variabel independen yang terkena multikolinieritas, maka penanggulangannya adalah salah satu variabel tersebut dikeluarkan (Ghozali, 2011:105).

\section{Tabel 6}

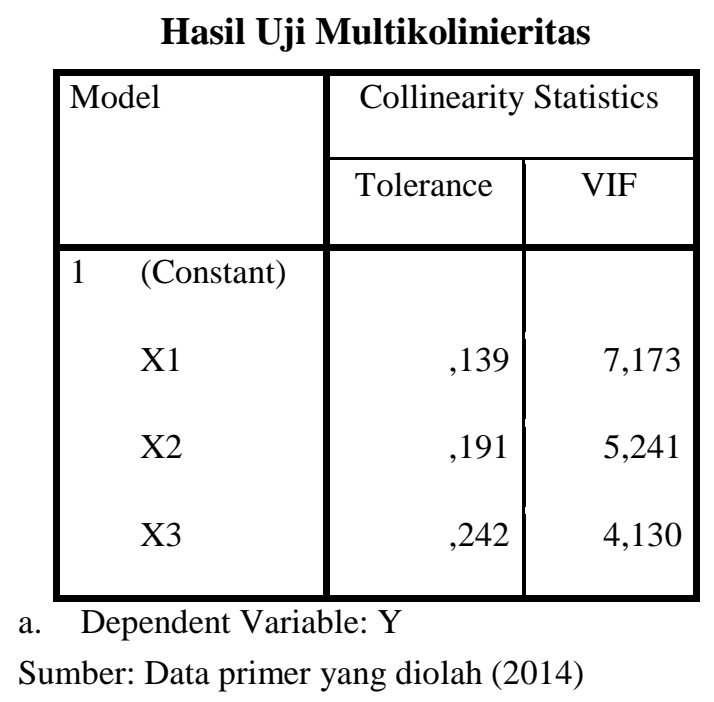

Berdasarkan tabel 6 tersebut hasil uji multikolinieritas menunjukkan bahwa semua variabel dalam model ini tidak terjadi multikolinieritas, karena semua variabel independen memiliki nilai tolerance lebih dari 0,1 $(>0,1)$ dan nilai VIF kurang dari $10(<10)$. Jadi dapat disimpulkan bahwa dari ketiga variabel tersebut tidak terjadi multikolinieritas atau bebas multikolinieritas. 


\section{Uji Heteroskedastisitas}

Uji heteroskedastisitas digunakan untuk menguji apakah dalam model regresi terjadi ketidaksamaan variance dari residual satu pengamatan ke pengamatan yang lain. Jika variance dari residual satu pengamatan ke pengamatan yang lain tetap, maka disebut dengan homoskedastisitas dan jika berbeda disebut heteroskedastisitas. Model regresi yang baik adalah yang homoskedastisitas atau tidak terjadi suatu heteroskedastisitas. Untuk mendeteksi ada tidaknya heteroskedastisitas, maka dapat dilakukan uji dengan cara melihat grafik plot antara nilai prediksi variabel dependen (ZPRED) dengan residualnya (SRESID). Apabila dalam grafik tersebut tidak terdapat pola tertentu yang teratur, maka dapat diidentifikasikan tidak terdapat heteroskedastisitas (Ghozali, 2011:139).

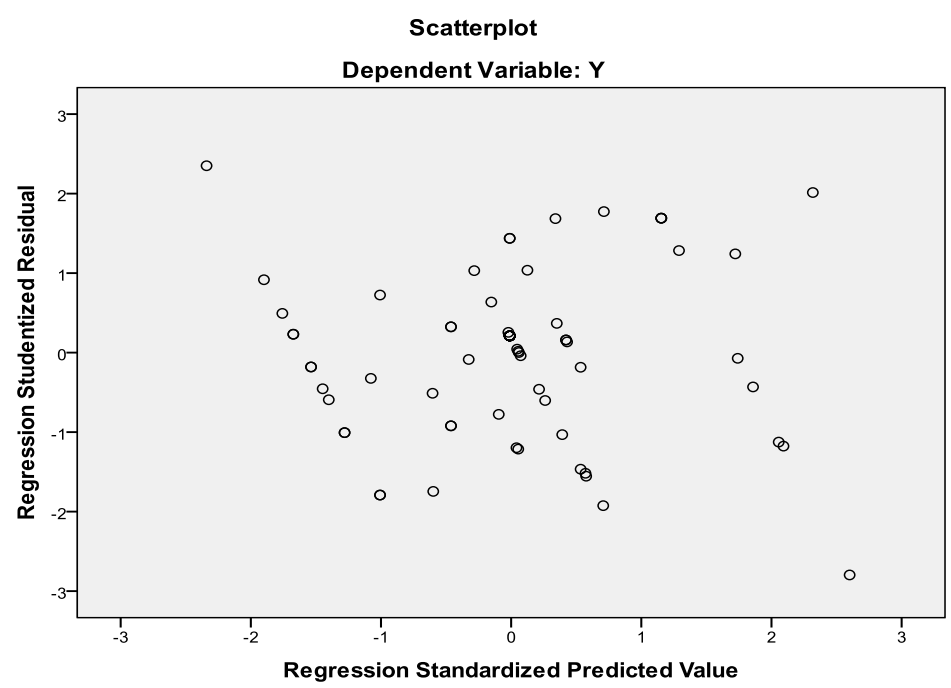

Gambar 3

\section{Hasil Uji Heteroskedastisitas dengan Scatterplot}

Sumber : Data primer yang diolah (2014)

Berdasarkan gambar 3 tersebut, menunjukkan bahwa model regresi tidak mengandung efek heteroskedastisitas. Hal ini terlihat dari titik-titik yang ada menyebar secara acak di atas dan di bawah angka 0 pada sumbu $\mathrm{Y}$ dan tidak membentuk pola tertentu. Jadi dapat disimpulkan bahwa model regresi ini tidak terjadi heteroskedastisitas atau bebas heteroskedastisitas.

\section{d. Analisis Regresi Linier Berganda}

Analisis regresi linier berganda (multiple regression) digunakan untuk menguji pengaruh lebih dari satu variabel bebas (metrik) terhadap satu variabel terikat metrik (Ghozali, 2011:17). Uji regresi linier berganda juga dapat menunjukkan arah hubungan antara variabel bebas (independent) dengan variabel terikat (dependent). Tabel berikut ini adalah hasil pengujian regresi linier berganda: 
Tabel 7

Hasil Uji Regresi Linier Berganda

Coefficients $^{\mathrm{a}}$

\begin{tabular}{|c|c|c|c|c|c|}
\hline Model & \multicolumn{2}{|c|}{$\begin{array}{c}\text { Unstandardiz } \\
\text { ed } \\
\text { Coefficients }\end{array}$} & $\begin{array}{c}\text { Standa } \\
\text { rdized } \\
\text { Coeffi } \\
\text { cients }\end{array}$ & & \\
\cline { 2 - 4 } & B & $\begin{array}{c}\text { Std. } \\
\text { Error }\end{array}$ & Beta & $\mathrm{T}$ & Sig. \\
\hline 1 (Cons \\
tant)
\end{tabular}

a. Dependent Variable: Y

Sumber : Data primer yang diolah (2014)

$Y=5,776+0,544 X_{1}+0,329 X_{2}-0,171 X_{3}+e$

- Konstanta sebesar 5,776 menyatakan bahwa apabila variabel standarisasi produk, pengelolaan pengetahuan dan teknologi informasi dianggap tetap, maka daya saing UKM akan meningkat sebesar 5,776.

- Nilai koefisien standarisasi produk sebesar 0,544 menyatakan bahwa apabila standarisasi produk naik satu poin sedangkan variabel lain dianggap tetap, maka daya saing UKM diprediksi akan meningkat sebesar 0,544.

- Nilai koefisien pengelolaan pengetahuan sebesar 0,329 menyatakan bahwa apabila pengelolaan pengetahuan naik satu poin sedangkan variabel lain dianggap tetap, maka daya saing UKM diprediksi akan meningkat sebesar 0,329.

- Nilai koefisien teknologi informasi sebesar - 0,171 dan bertanda negatif menyatakan bahwa teknologi informasi mempunyai hubungan yang berlawanan arah. Apabila teknologi informasi naik satu poin sedangkan variabel lain dianggap tetap, maka daya saing UKM diprediksi turun sebesar 0,171.

\section{Analisis Goodness of Fit}

\section{Koefisien Determinasi $\left(\mathbf{R}^{2}\right)$}

Koefisien determinasi $\left(\mathrm{R}^{2}\right)$ menunjukkan seberapa besar pengaruh variabel bebas (independent) terhadap variabel terikat (dependen) yang dinyatakan dalam persentase (\%). 
Tabel 8

Hasil Uji Koefisien Determinasi $\left(\mathbf{R}^{2}\right)$

\begin{tabular}{|c|r|r|r|r|}
\hline Model & $\mathrm{R}$ & R Square & $\begin{array}{l}\text { Adjusted } \\
\text { R Square }\end{array}$ & $\begin{array}{r}\text { Std. Error of } \\
\text { the Estimate }\end{array}$ \\
\hline 1 &, $949^{\mathrm{a}}$ &, 900 &, 896 &, 82070 \\
\hline
\end{tabular}

a. Predictors: (Constant), X3, X2, X1

b. Dependent Variable: $\mathrm{Y}$

Sumber : Data primer yang diolah (2014)

Nilai Koefisien determinasi (R2) pada tabel 8 tersebut menunjukkan nilai adjusted $R$ Square sebesar 0,896. Hal ini memiliki arti bahwa variabel terikat (dependent) yaitu daya saing UKM dapat dijelaskan oleh variabel bebas (independent) yang terdiri dari standarisasi produk, pengelolaan pengetahuan dan teknologi informasi sebesar $89,6 \%$ sedangkan sisanya 10,4\% dipengaruhi oleh faktor-faktor lain di luar variabel yang diteliti.

\section{Uji Kesesuaian Model (Uji F)}

Uji statistik F pada dasarnya menunjukkan apakah semua variabel independen atau bebas yang dimasukkan dalam model mempunyai pengaruh secara bersama-sama terhadap variabel dependen atau terikat (Ghozali, 2011:98).

Tabel 9

Hasil Uji Statistik F

\begin{tabular}{|ll|c|c|}
\hline Model & & F & Sig. \\
\hline 1 & Regression & 216,226 &, $000^{\mathrm{a}}$ \\
& Residual & & \\
& & & \\
& Total & & \\
\hline
\end{tabular}

a. Predictors: (Constant), X3, X2, X1

b. Dependent Variable: $\mathrm{Y}$

Sumber : Data primer yang diolah (2014)

Berdasarkan tabel 9 tersebut dapat dilihat bahwa hasil uji statistik F adalah 216,226 dan nilai signifikansinya adalah 0,000. Sehingga dapat disimpulkan bahwa persamaan variabel independen yaitu, standarisasi produk, pengelolaan pengetahuan dan teknologi informasi secara bersama-sama berpengaruh terhadap variabel dependen yaitu daya saing UKM, karena nilai signifikansinya lebih kecil dari 0,05 atau $(0,000<0,05)$, sehingga dapat disimpulkan bahwa model dalam penelitian ini baik. 


\section{Uji Parameter Model (Uji t)}

Uji t pada dasarnya menunjukkan seberapa jauh pengaruh satu variabel independen secara individual dalam menerangkan variasi variabel dependen. Pengujian ini dimaksudkan untuk menguji apakah regresi yang diperoleh itu berpengaruh positif, negatif atau tidak berpengaruh serta menentukan apakah hipotesis yang diajukan berhasil diterima atau tidak dapat diterima.

Berdasarkan pada tabel 7 Hasil Uji Regresi Linier Berganda menunjukkan bahwa ketiga variabel independen yaitu standarisasi produk, pengelolaan pengetahuan dan teknologi informasi yang dimasukkan ke dalam model regresi memiliki nilai signifikansi masingmasing yaitu standarisasi produk sebesar 0,000 , pengelolaan pengetahuan sebesar 0,000 dan teknologi informasi sebesar 0,018.

\section{PEMBAHASAN}

\section{a. Standarisasi Produk berpengaruh Positif terhadap Daya Saing UKM}

Hasil regresi variabel standarisasi produk diperoleh nilai probabilitas 0,000 yang menunjukkan lebih kecil dari 0,05. Karena nilai signifikansi pengujian lebih kecil dari $0,05(0,000<0,05)$, maka dapat disimpulkan bahwa $\mathrm{H}_{0}$ ditolak dan $\mathrm{H}_{1}$ dapat diterima. Hal ini berarti bahwa terdapat pengaruh positif dan signifikan dari variabel bebas standarisasi produk terhadap variabel terikat daya saing UKM.

Berdasarkan hasil penelitian tersebut menunjukkan bahwa standarisasi produk yang dilakukan oleh UKM Pengecoran Logam di Ceper berpengaruh positif terhadap daya saing UKM. Oleh karena itu apa yang sudah dilakukan oleh UKM Pengecoran Logam di Ceper terkait dengan standarisasi produk dapat terus dipertahankan dan ditingkatkan kualitas standar produknya, agar produk dapat diterima di pasar, memiliki nilai tambah pada produk, dapat meningkatkan kerjasama strategis sehingga produk-produk yang dihasilkan dapat di respon oleh pasar baik dalam negeri maupun luar negeri. Menurut Utterback dalam Allen (2000), standarisasi produk diperlukan untuk menjamin performansi, kesesuaian, dan keamanan dari suatu produk yang dihasilkan maupun prosesprosesnya. Standarisasi inilah yang akan membedakan produk di pasaran, mana yang baik dan mana yang tidak baik. Oleh karena itu, standarisasi memegang peran penting baik dalam tahap penelitian, pengembangan produk, maupun pada proses pengembangan produk di pasaran (Blind, 2008).

\section{b. Pengelolaan Pengetahuan berpengaruh Positif terhadap Daya Saing UKM}

Hasil regresi variabel pengelolaan pengetahuan diperoleh nilai probabilitas 0,000 yang menunjukkan lebih kecil dari 0,05. Karena nilai signifikansi pengujian lebih kecil dari $0,05(0,000<0,05)$, maka dapat disimpulkan bahwa $\mathrm{H}_{0}$ ditolak dan $\mathrm{H}_{1}$ dapat diterima. Hal ini berarti bahwa terdapat pengaruh positif dan signifikan dari variabel bebas pengelolaan pengetahuan terhadap variabel terikat daya saing UKM.

Berdasarkan hasil penelitian tersebut menunjukkan bahwa pengelolaan pengetahuan yang dilakukan oleh UKM Pengecoran Logam di Ceper berpengaruh positif terhadap daya saing UKM. Oleh karena itu pengelolaan pengetahuan yang sudah dilakukan oleh UKM Pengecoran Logam di Ceper dapat terus dipertahankan dan ditingkatkan dengan 
memberikan pelatihan maupun pengetahuan kepada karyawan secara rutin dan terus menerus agar karyawan dapat mengembangkan pengalaman, pengetahuan, ketrampilan maupun daya kreasinya agar produk yang dihasilkan menjadi lebih inovatif dan berdaya saing tinggi. Pengelolaan pengetahuan secara luas diartikan sebagai pengelolaan atau manajemen dari pengetahuan organisasi untuk menciptakan nilai bisnis dan membangun daya saing. Karena itu dengan pengelolaan pengetahuan yang baik organisasi mampu untuk menciptakan, mengkomunikasikan, dan mengaplikasikan pengetahuan ke segala macam kegiatan bisnis untuk pencapaian tujuan bisnis. Pemimpin organisasi mulai memahami proses kreasi pengetahuan karyawan sebagai keunggulan daya saing perusahaan dengan memobilisasi pengetahuan karyawan (Rachmany \& Akib, 2002).

\section{c. Teknologi Informasi berpengaruh Positif terhadap Daya Saing UKM}

Hasil regresi variabel teknologi informasi diperoleh nilai probabilitas 0,018 yang menunjukkan lebih kecil dari 0,05. Karena nilai signifikansi pengujian lebih kecil dari $0,05(0,018<0,05)$, dan koefisien $\beta$ adalah - 0,171 maka dapat disimpulkan bahwa baik $\mathrm{H}_{0}$ dan $\mathrm{H}_{1}$ ditolak. Hal ini berarti bahwa variabel bebas teknologi informasi berpengaruh kecil dan bertolak belakang terhadap variabel terikat daya saing UKM.

Berdasarkan hasil penelitian tersebut menunjukkan bahwa teknologi informasi yang dilakukan oleh UKM Pengecoran Logam di Ceper berpengaruh kecil dan bertolak belakang terhadap daya saing UKM. Hal ini dapat diartikan bahwa selama ini para pemilik UKM Pengecoran Logam yang ada di Ceper sudah memanfaatkan teknologi informasi hanya saja masih manual yaitu hanya dengan menggunakan HP dan masih sangat jarang yang menggunakan atau memanfaatkan jaringan internet. Oleh karena itu UKM Pengecoran Logam yang ada di Ceper sebaiknya sudah mulai beralih dengan menggunakan teknologi informasi seperti komputer yang terintegrasi dengan jaringan internet supaya pemilik UKM dapat secara langsung mengenalkan dan memasarkan produk-produknya tidak hanya di pasar domestik tetapi bisa sampai keluar negeri dengan memanfaatkan teknologi internet. Hal ini penting sekali bagi UKM supaya produk yang dihasilkan oleh UKM Pengecoran Logam yang ada di Ceper dapat dikenal dan bersaing dengan produk-produk yang lain baik di pasar domestik maupun internasional. Karena teknologi informasi menggunakan teknologi komputer dan teknologi jaringan untuk menghasilkan berbagai produk yang praktis serta layanan informatika yang terintegrasi, memberikan kemudahan, dan bersifat global. Pengalaman di beberapa negara menunjukkan bahwa penggunaan teknologi informasi oleh perusahaan dapat meningkatkan efektivitas dan efisiensi kerja serta meningkatkan produktivitas perusahaan, yang pada akhirnya meningkatkan daya saing perusahaan tersebut (Rianto, 2007).

\section{PENUTUP}

\section{Kesimpulan}

a. Standarisasi produk berpengaruh positif dan signifikan terhadap daya saing UKM. Hal ini berarti bahwa semakin baik standarisasi produk yang dilakukan oleh UKM akan meningkatkan daya saing UKM. 
b. Pengelolaan pengetahuan berpengaruh positif dan signifikan terhadap daya saing UKM. Hal ini berarti bahwa semakin baik pengelolaan pengetahuan yang dilakukan oleh UKM akan meningkatkan daya saing UKM.

c. Teknologi informasi berpengaruh kecil dan bertolak belakang terhadap daya saing UKM. Hal ini berarti bahwa teknologi informasi yang dilakukan UKM saat ini masih kecil pengaruhnya terhadap peningkatan daya saing UKM.

\section{Saran}

Karena teknologi informasi berpengaruh kecil, maka sebaiknya UKM Pengecoran Logam yang ada di Ceper sudah saatnya mulai menggunakan teknologi informasi seperti HP atau komputer yang terintegrasi dengan jaringan internet supaya pemilik UKM dapat secara langsung mengenalkan dan memasarkan produk-produknya tidak hanya di pasar domestik tetapi bisa sampai keluar negeri. Karena teknologi informasi menggunakan teknologi komputer dan teknologi jaringan untuk menghasilkan berbagai produk yang praktis serta layanan informatika yang terintegrasi, memberikan kemudahan, dan bersifat global, sehingga produk UKM dapat bersaing dengan produk lain.

\section{Implikasi Manajerial}

a. Berdasarkan hasil penelitian, standarisasi produk berpengaruh positif terhadap daya saing UKM. Oleh karena itu UKM Pengecoran Logam di Ceper terus mempertahankan standarisasi produk dan meningkatkan kualitas standar produknya, agar produk dapat diterima di pasar, memiliki nilai tambah pada produk, dapat meningkatkan kerjasama strategis sehingga produk-produk yang dihasilkan dapat di respon oleh pasar baik dalam negeri maupun luar negeri, sehingga produk yang dihasilkan UKM dapat bersaing dengan produk lain.

b. Berdasarkan hasil penelitian, pengelolaan pengetahuan berpengaruh positif terhadap daya saing UKM. Oleh karena itu pengelolaan pengetahuan yang sudah dilakukan oleh UKM Pengecoran Logam di Ceper dapat dipertahankan dan ditingkatkan kreativitasnya dengan memberikan pelatihan maupun pengetahuan kepada karyawan secara rutin dan terus menerus agar karyawan dapat mengembangkan pengalaman, pengetahuan, ketrampilan maupun daya kreasinya agar produk yang dihasilkan menjadi lebih inovatif dan berdaya saing tinggi.

c. Berdasarkan hasil penelitian, teknologi informasi berpengaruh kecil dan bertolak belakang terhadap daya saing UKM. Oleh karena itu sebaiknya para pemilik UKM Pengecoran Logam yang ada di Ceper harus sudah saatnya untuk memanfaatkan teknologi informasi seperti HP dan komputer yang terintegrasi dengan jaringan internet supaya dapat secara langsung mengenalkan dan memasarkan produk-produknya tidak hanya di pasar domestik tetapi bisa sampai keluar negeri dengan memanfaatkan teknologi internet, sehingga produk yang dihasilkan dapat dikenal dan bersaing dengan produk-produk yang lain baik di pasar domestik maupun internasional.

\section{DAFTAR PUSTAKA}

Arjadi, RH. dkk., Langkah-Langkah Strategis Untuk Peningkatan Daya Saing Produk Elektronika, Jakarta : LIPI Press, 2007, hal. 29

Allen, Robert H \& Ram D. Sriram. 2000. The Role of Standards in Innovation. Teknological Forecasting and Social Change 64. $171-181$. 
Altenburg, T., Hillebrand, W., and Meyer Stamer, J. 1998. Building Systemic Competitiveness: Concept and Case Studies from Mexico, Brazil, Paraguay, Korea and Thailand. German Development Institute, Reports and Working Papers 3/1998, Berlin : German Development Institute

Blind, Knut \& Andre Jungmittag. 2008. The Impact of Patent and Standards on Macroeconomic Growth: A Panel Approach Covering Four Countries and 12 Sectors. Journal of Productivity Analysis, Springer. Vol. 29 (1).

Daryanto, Arief dan Hafizrianda, Yundy (2010). Model-Model Kuantitatif Untuk Perencanaan Pembangunan Ekonomi Daerah : Konsep dan Aplikasi, Bogor: PT Penerbit IPB Press, 2010, hal. 11.

De Vries, Henk J. 1999. Standardization : A Nusiness Approach to the Role of National Standardization Organizations. Boston, Dordrecht, London : Kluwer Academic Publisher.

Drake, K. (2003). Firm, Knowledge and Competitiveness. The OECD Observer.

Ghozali, Imam (2009). Analisis Multivariate dengan Program SPSS. Edisi 3, Badan Penerbit Universitas Diponegoro, Semarang.

Ghozali, Imam (2011). Aplikasi Analisis Multivariate dengan Program IBM SPSS 19. Edisi 5, Badan Penerbit Universitas Diponegoro, Semarang.

Gudmundsson, Agnar, Harry Boer, \& Mariano Corso. 2004. The Implementation Process of Standardisation. Journal of Manufacturing Technology Management., Vol. 15 (4).

Jafar Hafsah, Mohammad (2004). Upaya Pengembangan Usaha Kecil dan Menengah (UKM), Infokop, Nomor 25 Tahun XX, 2004.

Karl, A.K. (2003). Human Resource Management in The Knowledge Economy. The Academy of Management Executive. Vol. 17, Iss. 2.

Kettinger, William J, Varun Grover, Subashish Guha dan Albert H. Segars, 1994, Strategic Information Systems Revisited: A Study in Sustainability and Performance, MIS Quarterly, March, p.31-59.

Kadocsa, Gyorgy. 2006. Research of Competitiveness Factors of SME. Acta Polytecnica Hungarica. Vol. 3, No. 4, 2006.

Muttaqien, A. (2006). Membangun Perpustakaan Berbasis Konsep Knowledge Management: Tranformasi menuju Research College dan Perguruan Tinggi Berbasis Internasional.

Notoatmojo, Soekidjo (2010). Metodologi Penelitian Kesehatan, Jakarta : Rineka Cipta

O’Brien, J.A. (2005). Management Information System. Nine Edition, Pearson Prentice Hall. America.

"Perdagangan Indonesia - Cina", www.Kompas.com; diakses 17 Pebruari 2011

Porter, Michael. 1990. Keunggulan Bersaing: Menciptakan dan Mempertahankan Kinerja Unggul. Binarupa Aksara, Jakarta.

Raqchmany, H. \& Akib, H. (2002). Rekontruksi Manajemen Pengetahuan. Majalah manajemen.

Rasbin dan Ginting, Ari M. Upaya Peningkatan Ekspor Sektor Usaha Mikro, Kecil dan Menengah melalui Peningkatan Daya Saing Produk, Jurnal Ekonomi dan Kebijakan Publik, Vol 2, No. 1 Juni 2011.

Rahmana, Arief. 2009. Peranan Teknologi Informasi dalam Peningkatan Daya Saing Usaha Kecil dan Menengah, Seminar Nasional Aplikasi Teknologi Informasi (SNATI), 2009.

Rianto, Y., Aminulla, E., Laksani, CS., Prihadyanti, D., Triyono, B., dan Handoko, L.T. 2007. Peta dan Strategi Teknologi Informasi di UKM Manufaktur.Jakarta: LIPI Press.

Setiarso, Bambang (2005), Strategi Pengelolaan Pengetahuan Untuk Meningkatkan Daya Saing UKM, Proceeding, Seminar Nasional, 2005. 
Skyrme, D.J. (2003). Knowledge Management: Making Sense of an Oxymoron

Sumihardjo, Tumar. 2011. "Konsep Daya Saing”, www.sambasalim.com; diakses 16 Maret 2011.

Sugiyono (2009). Metode Penelitian Bisnis. Bandung, CV. Alfabeta

Soegiyono (2010). Metode Penelitian Pendidikan (Pendekatan Kuantitatif, Kualitatif, dan R\&D). Bandung, CV. Alfabeta.

Susanty, Aries dkk. 2009. Hubungan Standar Produk dengan Inovasi Produk pada Industri Elektronik.

Tambunan, Tulus T.H. UMKM di Indonesia, Bogor: Ghalia Indonesia, 2009.

Tambunan, Tulus T.H. 2008. "SME Development in Indonesia with Reference to Networking, Innovativeness, Market Expansion and Government Policy”. ERIA Research Project Report 2007, No. 5, March, Bangkok : ERIA

Tiwana, Amrit. "The Knowledge Management Toolkit Practical Techniques for Building a Knowledge Management System", Prentice Hall, Singapore, 2000.

“UKM Terdesak Produk Impor", Harian Bisnis Indonesia, 25 Oktober 2010)

"Wapres, SNI Topang Daya Saing UMKM", www.bataviase.co.id, 22 Pebruari 2011

Widayanti, (2008). "Peran Teknologi Informasi untuk Mencapai Keunggulan Kompetitif", Jurnal Akuntansi dan Sistem Teknologi Informasi, Vol 6, No. 1, April 2008.

Warta KUMKM, edisi semester I - 2012, Direktorat Pemberdayaan Koperasi dan UMKM , Standards and Innovation. National Standadization Strategic Framework. http://www.bsigroup.com/upload/. 04 Mei 2009

, Standarisasi Produk UKM. Enterprise Asia. 1 September 2012. 